indebted to Dr. R. J. Lythgoe for the photographs and to Mr. C. W. Wilson for designing the apparatus for irradiation while he was physicist to the Strangeways Laboratory.

\title{
REFERENCES
}

Fisher, R. A.- "Statistical Methods for Research Workers." London, 1936.

Gladstone, R. J. and Colwell, H.- " On Some Effects of X-rays on the Leveloping Chick Embryo." Jl. Anat., Vol. LXVIII, p. 85, 1933.

Glücksmann, A. and Tansley. Katharine.- "Some Effects of Gamma Radiation on the Developing Rat Retina." Brit. Jl. of Ophthal., Vol. XX, p. 497, 1936.

Spear, F. G.-“"Tissue Culture and Radiological Research." Brit. Jl. Radiol., Vol. VIII, pp. 68 and 280, 1935.

Strangeways, T. S. P. and Oakeley, H.- "The Immediate Changes observed in Tissue Cells after Exposure to Soft X-rays while growing in vitro. Proc. Roy. Soc., Vol. XCV, p. 373, 1923.

Wilmer, E. N.- “'Tissue Culture." London, 1935.

Wilson, C. W., Hughes, A. F., Glücksmann, A., and Spear, F. G.-Bestrahlungsversuche an $\mathrm{Hühnerembryonen} \mathrm{in} \mathrm{vitro} \mathrm{und} \mathrm{in} \mathrm{vivo} \mathrm{mit} \mathrm{Radium} \mathrm{gamma-}$ strahlen. Strahlentherapie Bd. LII, S. 519, 1935.

\section{"THE ASSOCIATION OF DENDRITIC ULCER OF THE CORNEA AND OF SUPERFICIAL PUNCTATE KERATITIS WITH HERPES FACIALIS".}

BY

\section{HUMPHREY NeAME}

LONDON

THFSE combinations, especially that of all three, are rare. In the search through some of the ophthalmological literature of the last ten years for reports of cases such as will be described below, some references to disciform keratitis were found and are included, and a brief summary follows.

Case 1. C. G., aged 49 years.

Dendritic Ulcer with Herpes Febrilis of the Face.

November 22, 1926. Admitted to University College Hospital. "He came in with temperature of $102.6^{\circ}$, oedema of the scalp, herpetiform eruptions on both sides of his face" (House Physician's Notes).

On that date there was considerable dendritic ulceration of the right cornea (see Fig. 1). Dr. A. M. H. Gray diagnosed the lesions on the face as herpes febrilis.

P. H., " Out-patient at Western Ophthalmic Hospital in December, 1924, with nebula of right cornea. Slight ciliary injection; no staining. R.V. $=6 / 36$. L.V. $=6 / 9$ (partly). History of keratitis some years previously" (from House Surgeon). 


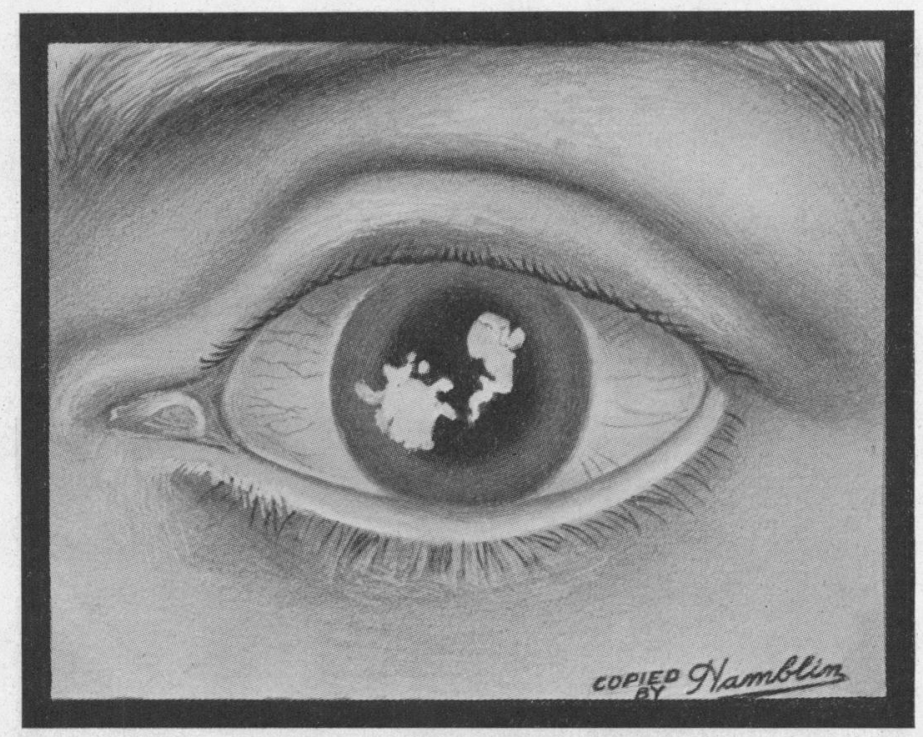

FIG. 1.

CASE 1. C. G. Drawing prepared from a sketch made by the writer at the time of examination on November 22, 1926. The opacity of the cornea is much exaggerated in the drawing, to show the extent of the ulceration.

December 6, 1926. A small central staining spot remains on the cornea.

February 6, 1936. No soreness of the eyes since 1927.

P. C. Nebulae of right cornea, surface smooth.

L. E. Two small "café au lait" "k.p." spots on posterior surface of cornea. Otherwise clear and surface smooth.

P. H. No history of spots on the face since 1927, except a sore on the lower lip, which occurred with a cold in the head and sneezing seven days ago. He thinks this sore was due to a cigarette sticking to the lip.

\section{Discussion}

The case was characterised by the presence of

1. A sharp febrile attack.

2. Marked herpetiform eruption of face.

3. Fairly extensive dendritic ulceration of cornea in two areas of $\frac{1}{4}$ to $\frac{1}{3}$ diameter of cornea in extent and a small round isolated spot about $0.5 \mathrm{~mm}$. in diameter. 
It is probably right to assume that the same kind of lesion affected the cornea and skin simultaneously, due to a common cause. Finlay refers to direct infection of the skin by herpes, and experiments show the possibility of infecting the cornea of man and animals directly through scarifications.

Case 2. C. C., aged 29 years (University College Hospital). Dendritic Ulcer with Herpes Febrilis.

On January 20, 1936, the patient complained of soreness of the left eye for the past few days.

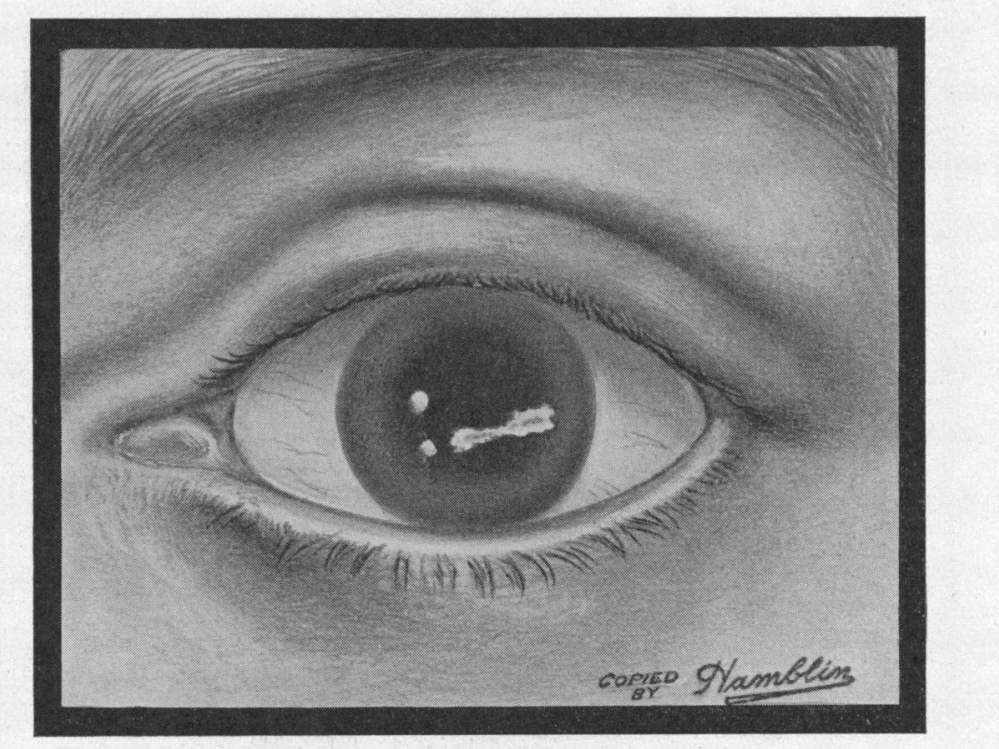

FIG. 2.

CASE 2. C. C. Drawing prepared from a diagram made by the writer at the time of examination on January 20,1936 , to show the size and distribution of the corneal lesions. The density of the opacities is much exaggerated.

Previous history.-At the end of December, 1935, he had a cold, starting as a cough, and later with running from the nose. With this was an eruption of groups of small blisters around the mouth and one patch at the outer end of the left eyelids.

His doctor (J. Mitchell Stewart of Ilford) reports that he has pulmonary tuberculosis and has had treatment by artificial pneumothorax, and states that the facial eruption was herpes febrilis.

Condition on January 20, 1936. Left eye slight ciliary injection; irregular roughening of cornea; staining shows dendritic 
ulceration (see Fig. 2) with two rounded flattened nodules also taking the stain. With the corneal microscope, these two areas are smooth and domed, entirely superficial. The ulcer shows a gutter-shaped depression within the ridge of raised margin.

February 5, 1936. No staining.

February 10, 1936. $\mathrm{R}+1 \cdot 0 \mathrm{sph} .=6 / 9 . \quad \mathrm{L}+1 \cdot 0 \mathrm{sph} .=6 / 36$.

\section{Discussion}

Although the skin eruption was not seen by the writer, there can be no doubt from the patient's description and the doctor's diagnosis that this was herpes facialis.

The corneal microscope showed the small smooth domed opacities to be entirely superficial. From the rough drawing the 2 spots seem to be approximately 0.5 to $1 \mathrm{~mm}$. in diameter. Their position-entirely superficial-as disclosed by the corneal microscope would not seem to allow of their being related to Doggart's Group A (limited to the anterior layers of the substantia propria only). The smoothness of the surface and the fact of their

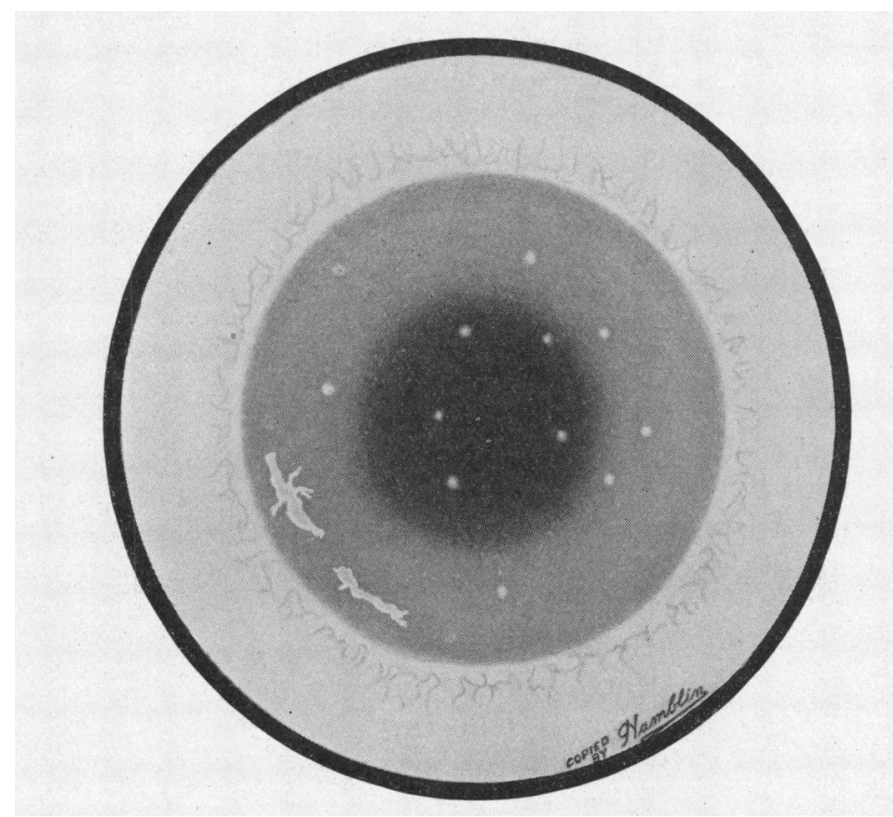

FIG. 3.

CASE 3. J. C. Drawing prepared from a diagram made by the writer at the time of examination in December, 1930, showing the size and position of the dendritic ulcers, and approximately the number and distribution of the spots of superficial punctate keratitis. 
being definitely raised does not, however, allow of their being classed as erosions. They may be compared with the spots of Dimmer's nummular keratitis as described by Aust, or with Wright's and Kirkpatrick's macular keratitis.

Case 3. J. C., age 28. (Moorfields Eye Hospital).

Dendritic Ulcer, Superficial Punctate Keratitis, and Herpes Febrilis of the face.

December, 1930. Recent soreness of left eye (2 weeks).

$P$. H. A history of an eruption on the face, which occurred frequently near the mouth, with a cold in the head accompanied by sneczing. The eruption was said to be unlike " yellow-heads" or pimples.

On examination on December 20, 1930, the right cornea was clear and glossy. Left conjunctival congestion. The left cornea showed numerous papules, grey, staining slightly by the method of deep staining with fluorescein. There were two dendritic ulcers in the inferior nasal part of the cornea, near the margin. Microscope and slit-lamp showed all lesions as being superficial. Typical herpes febrilis of the skin to the right side of the mouth.

On January 3, 1931, the left eye was white, no staining of the cornea, no papules, faint grey scars visible near the margin of the cornea in the inferior nasal region. No symptoms.

An examination was made again in January, 1936. There was no trace of corneal lesion, and no history of further trouble, apart from redness of the lid margins and slight conjunctival discharge, with a fissure of the outer canthus of the left eye present during the last three or four days.

\section{Discussion}

This is a case regarded as typical of superficial punctate keratitis, with numerous minute grey papules staining faintly from exposure for a few seconds to a 2 per cent. fluorescein solution. The drawing illustrates the impression received as to the number of spots on the cornea. These spots, in the writer's experience, always involve the surface, raising it in some cases to the most minute degree. This fact is in some only detected by studying carefully the anterior corneal reflecting zone with a strong focal illumination and a 10 magnification corneal loupe. This may be confirmed with the corneal microscope. In focal illumination, apart from the reflecting zone, the surface is apparently quite smooth. It is like that of a lake on a calm day which shows reflected mountains clear cut and unruffled. Where, however, the reflection of the sun as a broad brilliant band is seen stretched across the water there become manifest a myriad minute ripples. 


\section{Summary}

The cases described include :-

1. Facial dermatitis herpetiformis with fever, associated with dendritic ulcers.

2. Herpes around the mouth and on the eyelid, with a dendritic ulcer and two spots that may be classed as nummular or macular keratitis.

3. Typical superficial punctate keratitis with two small dendritic ulcers near the margin, in company with a lesion of herpes facialis on the right side of the chin.

It is probably true that herpes simplex (syn. H. febrilis, facialis, labialis, etc.) is a virus disease. It is claimed that the cases described are not merely rare coincidences, but that they support the contention that many cases of superficial punctate keratitis and its grosser forms-nummular or macular keratitis-and dendritic ulcers of the cornea are the result of infection with a virus capable of producing herpes simplex.

\section{Experimental Work}

Material obtained from human cornea the subject of superficial punctate keratitis has been applied to normal human cornea with positive results by Kirwan and by Wright. In the latter the incubation period was found to be from 3 to 9 days. Kirwan failed to transmit it to rabbits' cornea.

Scrapings from human dendritic ulcer infected a rabbit's cornea in 3 days, and material from that cornea was transferred to the fellow eye with similar positive results and the production of "typical dendritic ulcer with short branchings," also in 3 days. (Giza Memorial Ophthal. Lab.).

Human herpes febrilis material infected rabbits' cornea, and with material from the latter normal human cornea was inoculated with the development of typical dendritic ulceration. The reverse also applied. (R. I. Lloyd.) Herpes fluid infected the cornea of the rabbit, guinea-pig and white mouse, in some of which encephalitis developed and the second eye was occasionally affected. Kuchner claims to have obtained positive results (small superficial infiltrations along the lines of scarification) in inoculation of rabbits' cornea with human " herpes cornex" (cases " with marked herpetic configuration") in 32 out of 36 experiments when the material was taken not later than 13 days from the onset of the human disease; also from 2 out of 5 cases of disciform keratitis; but none in 12 experiments with different 
cases of recurrent abrasion of the cornea. These results are not very convincing as the rabbits' eyes were only watched for 2 days.

Grüter regarded 15 of 18 cases of disciform keratitis as herpetic in origin (Schieck Handbuch), but could only infect rabbits' cornea in 5 of these 15 cases, as he considered the virulence was lowered by the time the disciform keratitis was established. Of the remaining 3 cases, 1 was due to vaccination and 2 were the result of varicella.

\section{Pathogenesis}

A great variety of causes and of opinions as to causes of superficial punctate keratitis is found in the literature.

Berliner reports two cases of herpes labialis of 11 days duration, with multiple small grey lesions near the limbus of 17 days duration. These lesions appeared two days after the induction of hyperpyrexia by general diathermy. The corneal lesions left faint scars. He suggests that the body harboured the virus in an inactive form until the pyrexia developed. Electric light ophthalmia (Schieck); acute conjunctivitis (Elschnig); mild trachoma, swimming-pool conjunctivitis, tropical catarrhal conjunctivitis of Herbert; influenza (Schieck); measles (Trantas); the virus of herpes facialis (experimental evidence of Kirwan-see infra-) are all cited as causes of superficial punctate keratitis. Lloyd gives a long list of infections or the use of toxic substances which have been followed by the appearance of herpes cornea febrilis with superficial ulceration:-antityphoid inoculation, vaccination, therapeutic malaria injections, malaria, salvarsan injections, cerebro-spinal meningitis, common colds and herpes labialis.

So far as superficial punctate keratitis alone is concerned, Doggart endeavours to bring some order out of chaos by dividing cases into three groups. He regards Koby's remark, "Superficial punctate keratitis is a morphological conception," as a desirable description of a group of conditions of varying aetiology, duration and clinical signs. Doggart's groups are as follows :-

A. Non-recurrent superficial punctate keratitis in which the lesions are in anterior layers of the substantia propria only. It affects young adults, is non-recurring, but may last as long as two years. In his series of 43 cases it was unilateral except in four. In none was epithelial loss detected. The small grey dots persisted for from two weeks up to several months. Corneal sensation returns with the recovery of the cornea. It occurs in the winter months. 
B. Multiple erosions occur in influenza, acute conjunctivitis; as a result of chemical vapours, mustard gas or dust. The epithelium is involved with or without any affection of the superficial layers of the substantia propria. The lesions tend to recur, and are liable to be confused with slighter cases of dendritic ulcer.

C. A miscellaneous group with superficial corneal lesions, but no loss of polish.

Attention is drawn by various writers to the association of different corneal lesions or to types transitional between different corneal lesions. Berliner's two cases of herpes labialis and multiple corneal lesions following diathermic hyperpyrexia have been mentioned. Fage mentions two cases of herpes simplex corneæ which developed dendritic ulcers, and states that dendritic and disciform keratitis have been produced in animals by herpes virus. He considers that branched keratitis (Grut), radiating ulcerative keratitis (Gillet), dendritic keratitis (Emmert) and disciform keratitis are different forms of herpetic infection of the cornea. Rokitskaja reported three interesting cases of virus affection in one household; a male of 21 years had herpes zoster and disciform keratitis, whose sister aged 26 had herpes zoster and superficial punctate keratitis; their niece had chickenpox. These cases, although interesting from the point of view of the contagiousness of chickenpox virus, are hardly germane to the present discussion, as a deep corneal affection in herpes zoster is in some cases similar in clinical appearance and course to severe isolated disciform keratitis (as observed by the writer); also in other cases of herpes zoster ophthalmicus multiple superficial lesions have been described, and one was observed recently by the writer. In this case minute grey papules visible in magnification by a $\times 10$ loupe were scattered evenly over the cornea, six days after the onset of herpes ophthalmicus. Within a week the papules had all entirely disappeared. Nodules seen at the upper limbus were still present, but smaller.

Verhoeff (quoted by Doggart) assumes that some shock (e.g., toxin) to the ciliary or Gasserian ganglion is the cause of superficial punctate keratitis, and associates as resulting from a similar cause acne rosacea keratitis, recurrent abrasion and neuropathic keratitis. Sandomir reported two cases of disciform keratitis, one from recurrent herpes of the lip, the other from vaccine virus. Szekely found conditions transitional between nummular keratitis and disciform keratitis, and considers vesicular, superficial punctate and nummular keratitis to be forms of the same disease. Wright also refers to transitional cases between macular keratitis (of Kirkpatrick) and disciform keratitis, and regards macular 
keratitis as the same condition as the later stage of larger forms of superficial punctate keratitis. During the large epidemics of the latter described by him, only three cases of dendritic ulcer were noted, and of these one was associated with herpes labialis. 'There was only one other case of herpes labialis reported during the same period and it was free from corneal affection. Schieck divides virus affections of the cornea into three groups :-

1. Herpes simplex and dendritic ulcer.

2. Herpes zoster of the conjunctiva and cornea.

3. Disciform keratitis, keratitis profunda, superficial punctate keratitis and some cases of neuroparalytic keratitis. He regards herpetic diseases of the cornea as exogenous, and compares them with pneumococcal ulceration. He considers that a lesion of the epithelium allows entry of the virus. Vogt, on the other hand, holds the opinion that they are endogenous, but does not appear to be quite consistent when he urges that early cauterisation of a lesion is necessary in order to prevent the extension of the virus to the deeper layers of the cornea. He regards trauma as playing a rôle comparable with that of injury before the onset of interstitial keratitis-in that the area of lowered resistance is rendered susceptible to the virus already present in the body.

There is but little histological information upon this subject. The Giza Ophthalmological Laboratory workers examined sections of a rabbit's eye the subject of dendritic ulceration produced by corneal inoculation from a typical human dendritic ulcer. Numerous eosinophile granules, less than $0 \cdot 2 \mu$ in diameter, were found in the corneal corpuscles adjacent to the ulcer. None was seen in the epithelium. They were regarded as the histological evidence of the presence of a virus. Herbert described an encapsulated bacillus, $1.6 \times 3 \cdot 2 \mu$, in an epidemic of superficial punctate keratitis in India.* Wright was unable to obtain any confirmation that this organism was a causal agent. Ochapovski and Lipovski regard herpetic, vesicular and dendritic keratitis as the same histological process. Verhoeff found in superficial punctate keratitis usually no infiltration, but a small disc-shaped necrotic focus immediately deep to Bowman's membrane.

The most definite reports of association of different corneal conditions mentioned above are those of :-

1. Wright (1930), who noted transitional cases between the larger forms of superficial punctate keratitis (probably the same as those called by others nummular keratitis), and disciform keratitis; and also reported one case of dendritic ulcer associated with herpes labialis.

[ This paper was presented to the British Journal of Ophthalmology before the meeting of the Congress of the Ophthalmological Society, 1937, at which Wright made some remarks upon further bacteriological investigations relative to an encapsulated bacillus.] 
2. Fage (1932), whose case of herpes simplex corneæ developed into one of dendritic ulcer.

3. Szekely (1935), who also noted cases transitional between nummular keratitis and disciform keratitis.

4. Sandomir (1935), who reported disciform keratitis with herpes labialis.

\section{Aetiology}

Of aetiological factors, emphasis is laid on the seasonal occurrence as noted by several observers.

Wright's (1929-1930) curve of seasonal incidence showed the greatest number of cases between September and January, with a high peak in November and December. Doggart's (1933) series of superficial punctate keratitis had a winter prevalence. Kirwan's (1933) cases occurred during the rains of 1932 and the monsoon of 1933. Ochapovski and Lipovski (1934) found in Russia 60 per cent. of cases in the warm months. Possibly in such a cold climate the temperature was too low for the development of a virus infection of the cornea. In the 3 cases described by the present writer the disease started in November, December and January. It is of interest to note that of Elliot's 19 cases of herpes zoster in India 14 occurred between September and March (1918).

\section{Symptoms and Signs}

The onset of superficial punctate keratitis is often associated with catarrhal conditions of the respiratory tract (Fuchs). The corneal spots are deep to Bowman's membrane (Fuchs and Doggart), but according to Kirwan they start occasionally as corneal vesicles, and in Wright's epidemics of 3,500 cases the spots were usually raised. The latter also noted some cases with small limbal and conjunctival elevations in association with a few corneal spots near the margin. The corneal spots are about $0.5 \mathrm{~mm}$. in diameter. (Fuchs, quoted by Doggart.)

The spots in keratitis nummularis are 1 to $1.5 \mathrm{~mm}$. in diameter (Aust). Lloyd observed dendritic keratitis to start as a group of very small blisters which link up and form a tree-branching ulcer, and Foster Moore noted the association of herpes corneæ with dendritic and stellate ulcers. Diminished corneal sensation was noted by Fuchs, and diminished lid sensation by Doggart (one third of the cases), whereas Wright found the corneal sensation usually normal, and Trantas (quoted by Doggart) found normal sensation in transient cases which occurred during measles. 
The keratitis was unilateral in 39 of 43 cases (Doggart), but bilateral in Trantas' series. It was bilateral in only 16 of 1,000 of Wright's later cases. Floating particles were noticed in the aqueous in some (Doggart and Wright), and iris hyperæmia was sometimes present (Fuchs and Doggart). Pre-auricular glands were enlarged only in severe examples (Kirwan). The duration of the spots was of 1 week in Trantas' series, 1-2 weeks in Kirwan's, 4-6 weeks in Aust's, and from a few weeks up to 2 years in Doggart's. The writer has observed them for over a year in one case.

If one virus is responsible for such a variety of lesions as herpes simplex corneæ, superficial punctate keratitis, nummular (or macular) keratitis, dendritic ulceration, disciform keratitis, some forms of neuropathic keratitis, and perhaps also keratitis profunda, it must be capable of very varied behaviour at different times and in different places. It is clear that Koby's and Doggart's contention is correct, namely, that superficial punctate keratitis is a manifestation of a number of different infections-e.g., herpes febrilis virus and herpes zoster virus (which may be allied), measles, malaria. It seems almost certain, however, that one virus-modified perhaps in different localities or in different years --is capable of producing a variety of lesions of the cornea. There is the liability that confusion may arise from the use of terms which have a different meaning to different persons. For example, in the absence of a definite description of the condition named " disciform keratitis," it is possible that to one person it implies a superficial lesion and to another deep. The use of the corneal microscope should help in the avoidance of such discrepancies. Further observations and reports of such cases will help to elucidate the problem.

\section{LITERATURE}

Aust, O.- "Keratitis Nummularis (Dimmer)." Arch.f. Ophthal., Vol. CXXIX, p. $576,1933$.

Berliner, M. L.- “ Herpes Corneae occurring after Artificial Hyperpyrexia induced by Diathermy." Arch. of Ophthal., Vol. X, p. 365, 1933.

Doggart, J. H.- "Superficial Punctate Keratitis." 'Brit. Jl. of Ophthal., Vol. XVII, p. $65,1933$.

Elliot, R. H.- "Some Observations on Herpes Zoster Ophthalmicus." Trans. Ophthal. Soc. U.K., Vol. XXXVIII, p. 351, 1918.

Fage.-" Variability of Forms of Herpes of the Cornea." Arch. d'Ophtal., Vol. XLIX, p. 578, 1932.

Findlay.-Proc. of the Roy. Soc. Med., Vol. XXIX, p. 563, 1936.

Giza Memorial Ophthal. Lab. Rep. Cairo. Ninth Annual Rep., p. 73, 1934

Grüter.- "Untersuchung ueber den sogennant Herpes Corneae." Heidelberg Ophthal. Ges., Vol. CLXII, 1920. (Quoted by Doggart)

Herbert, H. - "The Micro-organism of Indian Superficial Punctate Keratitis," Brit. Jl. of Ophthal., Vol. XV, p. 633, 1931.

Kirkpatrick.-“An Epidemic of Macular Keratitis." Brit. Jl. of Ophthal., Vol. IV, p. 16,1920 . 
Kirwan, E. O'G.- "Epidemic Superficial Punctate Keratitis in Bengal." Prcc. All-India Ophthal. Soc., Vol. III, p. 1, 1933.

Kuchner, K.- "Inoculations with Herpes Virus." Klin. Monatsbl. f. Augenheilk., Vol. XCI, p. 485, 1933.

Lloyd, R. I.- "Herpes and Allied Conditions." Amer. Jl. of Ophthal., Vol. XIV, p. 601,1931

Moore, R. F - "Ocular Manifestations of Lesions of the Fifth Nerve." British Medical Association Centenary Meeting. Brit. Med. Jl., July, 1932.

Ochapovski and Lipovski.- "Pathology of the Cornea ; Herpetic Keratitis." Sovietskii Viestriek. Ophtal., Vol. V, part 2, p. 109, 1934. (R. K. Daily, abstract in Amer. Jl. of Ophthal., Vol. XVIII, p. 191, 1935).

Rokitskaja. - "Aetiology and Pathogenesis of Herpes Zoster Ophthalmicus." Sovietskii Viestriek. Ophtal., Vol. VI, part 4, p. 453, 1935. (Abstract in Amer. Jl. of Ophthal, 1935).

Sandomir.- " Two Cases of Disciform Keratitis." Sovietskii Viestriek. Ophtal., Vol. VI, part 3, p. 411, 1935. (Abstract in Amer. Jl. of Ophthal., 1935).

Schieck, F.- "Kurzes Handbuch für Ophthal.

Szekely, J.- "Keratitis nummularis Dimmer." Graefe's Arch.f. Ophthal., Vol. CXXXIV, p. 184, 1935.

Vogt.-Slit-lamp Micrcscopy of the Living Eye. Second Edition.

Verhoeff.- " The Pathology of Keratitis Punctata Superficialis with Remarks on Neuropathic Keratitis." Arch. of Ophthal., Vol. XL, p. 486, 1911. (Quoted by Doggart, v. supra).

Wright.- "Superficial Punctate Keratitis." Brit. Jl. of Ophthal., Vol. XIV, p. $595,1930$.

\title{
BACTERIOLOGICAL AND EXPERIMENTAL RESEARCHES ON THE AETIOLOGY OF TRACHOMA
}

\author{
BY \\ Drs. A. CUÉNOD and R. NATAF \\ TUNIS
}

In the course of experimental researches on trachoma, commenced by one of us in collaboration with Charles Nicolle more than thirty years ago, and continued with him until 1922, important results were arrived at with regard to the experimental transmission of trachoma. We have shown that there is an infecting virus, and we have given its principal physiological characteristics, notably those of its filterability and of its long conservation in the testicle of the living rabbit ${ }^{1}$.

Does this virus which has been demonstrated physiologically and experimentally always remain invisible morphologically? Charles Nicolle, essentially an experimental physiologist, expressed an opinion on this point, which we as practising clinicians always ask ourselves, anxious as we are to have a sign, exact,

Note by translator, Mr. A. F. MacCallan :-It will be remembered that Cuénod was associated for many years with that distinguished director of the Pasteur Institute of Tunis, Charles Nicolle, in experimental pathological work on trachoma. This translation has been approved by the authors. 